\title{
Comparison of the antioxidant effects and physiological activities of grape fruit stem extracts derived with different drying methods
}

\author{
Kwang-Sup Youn ${ }^{1,2 *}$ \\ ${ }^{1}$ Department of Food Science and Technology, Daegu Catholic University, Gyeongsan 38430, Korea \\ ${ }^{2}$ Institute of Food Science and Technology, Daegu Catholic University, Gyeongsan 38430, Korea
}

\section{건조방법에 따른 포도 송이가지의 항산화 효과 및 생리활성 특성}

\author{
윤광섭 $1,2 *$ \\ ${ }^{1}$ 대구가톨릭대학교 식품공학전공, ${ }^{2}$ 대구가톨릭대학교 식품과학연구소
}

\begin{abstract}
This study was conducted to examine the utilization potential of grape stems as nutritional supplements, and the physiological functionalities of $\mathbf{7 0} \%$ ethanol extracts from grape fruit stem (GFS) were investigated. Each experimental group was prepared with different methods and included GFSF (GFS prepared with freeze drying), GFSI (GFS prepared with infrared drying), GFSH (GFS prepared with heat air drying), and GFSS (GFS prepared with sun drying). The respective yields of freeze-dried powders for the GFSF, GFSI, GFSH, and GFSS were $59.27 \%, 57.13 \%$, $\mathbf{5 8 . 5 7 \%}$, and $\mathbf{5 8 . 8 7 \%}$, respectively. Total polyphenol contents in the GFSF were significantly greater than those in the other extracts, whereas total flavonoid contents in the GFSI were higher than those in the other extracts. The contents of proanthocyanidin-related substances were ranked in the order of GFSF $>$ GFSI $>$ GFSH $>$ GFSS. The thin layer chromatograph (TLC) analysis of catechin showed that the GFSF, GFSI, GFSH, and GFSS were detected in the same band. The electron donating ability with $500 \mu \mathrm{g} / \mathrm{mL}$ (w/v) solutions of GFSF, GFSI, GFSH, and GFSS amounted to $93.14 \%, 93.07 \%, 92.64 \%$, and $86.95 \%$, respectively, and the reducing powers (OD 700 ) were 1.933, 1.765, 1.455, and 1.200 absorbance units, respectively. Additionally, the ABTS radical scavenging ability showed the same tendency that was observed with the electron donating ability and reducing power. The angiotensin-converting enzyme (ACE) inhibitory activity and tyrosinase inhibitory activity with $500 \mu \mathrm{g} / \mathrm{mL}(\mathrm{w} / \mathrm{v})$ solutions of GFSF and GFSI were higher than those of GFSH and GFSS. In conclusion, the infrared drying technique is the superior method for the enhancement of biological activity for by-product utilization.
\end{abstract}

Key words : grape fruit stem, drying method, physiological, functionalities

\section{서 론}

노화란 세포와 신체조직 전 기관에 걸쳐 일어나는 기능 적, 구조적, 생화학적 변화에 의하여 체내의 항상성이 붕괴 되는 과정을 말한다. 그 원인으로 피부의 구조적 변화와 생리적 기능이 감소하여 나타나는 자연적 노화(intrinsic

*Corresponding author. E-mail : ksyoun@cu.ac.kr Phone : 82-53-850-3209, Fax : 82-53-850-3209

Received 11 April 2018; Revised 14 June 2018; Accepted 20 June 2018.

Copyright (c) The Korean Society of Food Preservation. All rights reserved. aging), 그리고 외부 자극 등 산화적 스트레스에 의한 광노 화(photoaging)로 구분된다. 산화적 스트레스의 경우 free radical의 일종인 활성산소종(reactive oxygen species, ROS) 에 의하여 발생되며 이들은 생체막에 존재하는 불포화 지방 산을 산화시켜 세포의 불활성화를 일으키는 작용을 통하여 노화 및 각종 질병 발생에 기여하게 된다(1). 노화와 성인병 질환의 원인이 활성산소라는 학설이 인정되면서 butylated hydroxyanisole(BHA), butylated hydroxytoluene(BHT) 등과 같은 합성 항산화제 개발 연구가 진행되어 왔으나 이들의 경우 항산화능은 우수한 반면 독성이 지적됨에 따라 보다 안전하고 효능이 우수한 천연 생리활성물질 개발이 요구되 고 있다. 
최근 국민 식생활 수준의 개선과 가공 산업의 발달로 각종 농산 생산물들의 상당량이 산업적으로 가공처리 되고 있으나 제조 과정 중에 대량의 부산물이 발생하고 있으며, 이들 대부분은 폐기되고 있어 이를 자원화 하려는 연구가 다각적으로 이루어지고 있다(2). 특히 천연물의 미량 원소 중 폴리페놀성 화합물 항산화제가 질환의 예방 및 치료제로 서 관심을 끌고 있으며 부산물을 활용한 고부가가치의 기능 성 소재로 이용될 수 있는 천연신소재 발굴이 주목을 받고 있다.

포도는 갈대나무목(Rhamnales) 포도과(Vitis vinifera)에 속하는 덩굴성과수로, 포도과에는 11속 700여종이 있으며 주로 열대 및 아열대 지역에서 자생하고 일부는 온대지방에 분포한다. 전 세계적으로 광범위하게 재배되고 있으며 세 계 과일 생산량의 약 $30 \%$ 를 차지하고 국내에서는 연간 40 만 톤의 포도가 생산되고 있다(3). 포도에는 전화당을 비롯한 유기산과 미네랄, 탄닌, 각종 비타민 외에 인체에 유익한 작용을 하는 플라보노이드계 식물화학 성분이 있으 며, 주요 페놀성 화합물 구성 요소로는 procyanidins, anthocyanins, viniferine 및 resveratrol 등이 알려지고 있다 (4). 특히, resveratrol(trans-3,5,4-trihydroxystilbene, $\mathrm{C}_{14} \mathrm{H}_{12} \mathrm{O}_{3}$ ) 은 phytoalexin 계열의 폴리페놀 물질로서 지방 과산화 억 제, 항산화, 항콜레스테롤, 항염증, 항암, 혈소판 응집 억제, 심혈관계 질환 방지, 신경보호작용 및 수명연장 등의 효과 가 보고되고 있으며 $(5,6)$ 그 함량은 과육에 비하여 버려지는 포도 송이가지에 가장 많이 함유되어 있다고 알려진 바 있다(7).

건조 및 가공방법에 따른 Campbell Early 종의 포도에서 폴리페놀, 플라보노이드 함량 및 항산화능의 차이를 나타 내는 것으로 보고하여 고부가가치 가공품 개발에 가능성을 제시한 바 있어(8,9), 본 연구에서는 포도 부산물의 활용을 위한 기초연구로서 포도 송이가지의 건조방법에 따른 생리 활성을 측정함으로써 기능성 소재으로서의 개발 가능성을 검토하고자 하였다.

\section{재료 및 방법}

\section{재 료}

본 실험에서 사용된 포도 송이가지는 경북 영천에서 수 확한 Muscat Bailey A 품종을 사용하였으며, 항산화 효과를 측정하기 위해 사용한 시약으로 Folin-Ciocalteu reagent, gallic acid, rutin hydrate, (+)-catechin, vanillin, 1,1diphenyl-2-picryl-hydrazyl, 2,2'-azino-bis(3-ethylbenzothiazoline6-sulfonic acid) diammonium salt, rabbit lung acetone powder, Hippuryl-histidyl-leucine, mushroom tyrosinase, arbutin, dibutyl hydroxy anisole 및 dibutyl hydroxy toluene은 Sigma-Aldrich Chemical Co.(St. Louis, MO, USA)에서 구입
을 하였으며, sodium carbonate, ascorbic acid, sodium carbonate, sodium nitrite, aluminium chloride, potassium ferricyanide, trichloroacetic acid, potassium persulfate 및 ethyl acetate는 Junsei Co.(Tokyo, Japan)의 1 급 및 특급시약 을 사용하였다.

\section{포도 송이가지 건조}

동결건조는 freeze dryer(FD SFDSM12, Samwon, Korea) 로 건조하였으며, 적외선건조는 infrared dryer(IRD-250, Woori Sci, Seoul, Korea)를, 열풍건조는 hot air dryer (OF-22GW, Jeiotec., Daejeon, Korea)를 각각 이용하여 $60^{\circ} \mathrm{C}$ 에서 일정수분함량까지 건조하였다. 천일건조는 통풍이 잘 되는 곳에서 일광에 노출시켜 8-10일간 건조하였으며, 각각 의 건조물은 균질기(Nihonseili, Kaisha Ltd., Japan)를 사용 하여 $40 \mathrm{mesh}$ 로 분쇄한 후 분말을 제조하여 실험에 사용하 였다.

\section{시료의 추출 및 수율 측정}

건조 방법에 따른 포도 송이가지의 에탄올 추출물을 얻 기 위하여 각각 건조된 분말 시료를 $70 \%$ 에탄올 용매에 $1: 8$ 의 비율로 넣고 $60^{\circ} \mathrm{C}$ 의 맨틀 상에서 3 시간씩 3 회 반복 추출한 후 Whatman No.1여과지로 여과하였다. 다음 rotary vacuum evaporator(rotary vacuum evaporator $\mathrm{N}-\mathrm{N}$ series, Eyela, Tokyo, Japan)로 감압농축한 후에 동결건조하여 분 말 시료를 제조하였으며 $-70^{\circ} \mathrm{C}$ 에 보관하면서 실험에 사용 하였다. 각 추출물들의 수율(\%)은 추출액을 동결 건조시켜 건물 중량을 구한 다음 추출액 조제에 사용한 원료 건물량 에 대한 백분율로 계산하였다.

\section{색 도}

색도는 색차계(Chromameter CR-200 Minolta, Tokyo, Japan)로 측정하였으며, 밝기를 나타내는 $\mathrm{L}^{\star}$ (lightness), 적 색도를 나타내는 $\mathrm{a}^{*}$ (redness), 황색도를 나타내는 $\mathrm{b}^{*}$ (yellowness) 및 $\mathrm{H}^{\circ}$ (hue angle value)를 측정하였다.

\section{폴리페놀 함량 측정}

Dewanto 등(10)의 방법에 따라 시료 $100 \mu \mathrm{L}$ 에 $2 \%$ sodium carbonate $2 \mathrm{~mL}$ 과 50\% Folin-Ciacalteu reagent $100 \mu \mathrm{L}$ 을 가한 후 $720 \mathrm{~nm}$ 에서 흡광도를 측정하였으며 gallic acid (Sigma-Aldrich Co.)의 검량선에 의하여 함량을 산출하였 다.

\section{플라보노이드 함량 측정}

Saleh와 Hameed(11)의 방법에 따라 시료 $100 \mathrm{~mL}$ 에 5\% sodium nitrite $0.15 \mathrm{~mL}$ 을 가한 후 $25^{\circ} \mathrm{C}$ 에서 6 분간 방치한 다음 $10 \%$ aluminium chloride $0.3 \mathrm{~mL}$ 를 가하여 $25^{\circ} \mathrm{C}$ 에서 5 분간 방치하였다. 다음 $1 \mathrm{~N} \mathrm{NaOH} 1 \mathrm{~mL}$ 를 가하고 vortex상 
에서 가한 후 $510 \mathrm{~nm}$ 에서 흡광도를 측정하였으며 rutin hydrate(Sigma-Aldrich Co.)의 검량선에 의하여 함량을 산출 하였다.

\section{프로안토시아니딘 함량 측정}

Vanillin-sulfuric acid법(12)에 따라 시료 $200 \mu \mathrm{L}$ 에 $1.2 \%$ vanillin 용액 $500 \mu \mathrm{L}$ 와 $20 \%$ sulfuric acid $500 \mu \mathrm{L}$ 를 혼합하여 20 분간 방치한 후 $500 \mathrm{~nm}$ 에서 흡광도를 측정하였으며 (+)-catechin(Sigma-Aldrich Co.)의 검량선에 의하여 함량을 산출하였다.

\section{TLC에 의한 카테킨 정성 분석}

Thin layer chromatography(TLC)의 조건은 Andriambeloson 등(13)의 방법을 변용하였으며, 분리한 획분을 silica plate (Merck, Darmstadt, Germany)에 spotting한 후 toluene/ acetone/formic acid(6:6:1, v/v/v)의 혼합용매로 전개하였다. 발색제로 $70 \%$ hydrochloric acid에 녹인 $1 \%$ vanillin 용액을 사용하였으며 (+)-catechin(Sigma-Aldrich Co.)을 표준품으 로 하여 추출물 중의 catechin을 정성 분석하였다.

\section{전자공여능}

Blois(14)의 방법에 따라 시료 $0.2 \mathrm{~mL}$ 에 $0.4 \mathrm{mM}$ 1,1diphenyl-2-picryl-hydrazyl(DPPH)용액 $0.8 \mathrm{~mL}$ 를 가하여 10 분간 방치 한 다음 $525 \mathrm{~nm}$ 에서 흡광도를 측정하였으며 계산식, electron donating ability $(\%)=100-[(\mathrm{OD}$ of sample/ $\mathrm{OD}$ of control)×100]에 의하여 활성도를 산출하였다.

\section{환원력 측정}

Saeedeh와 Asna(15)의 방법에 따라 시료 $1 \mathrm{~mL}$ 에 $0.2 \mathrm{M}$ phosphate buffer(pH 6.6) $2.5 \mathrm{~mL}$ 와 $1 \%$ potassium ferricyanide 용액 $2.5 \mathrm{~mL}$ 를 가한 후 $50^{\circ} \mathrm{C}$ 에서 30 분간 반응시켰다. 다음 에 $10 \%$ trichloroacetic acid(TCA) 용액 $2.5 \mathrm{~mL}$ 를 가한 후 $1,650 \times g$ 에서 10 분간 원심분리 하였으며, 상등액 $2.5 \mathrm{~mL}$ 에 증류수 $2.5 \mathrm{~mL}$ 와 $0.1 \% \mathrm{FeCl}_{3}$ 용액 $0.5 \mathrm{~mL}$ 를 가한 후 700 $\mathrm{nm}$ 에서 흡광도를 측정하였다.

\section{ABTS radical 소거활성 측정}

$\operatorname{Re}$ 등(16)의 방법에 따라 $7.4 \mathrm{mM} \mathrm{2,2'-azino-bis(3-}$ ethylbenzothiazoline-6-sulfonic acid) diammonium salt(ABTS) 와 $2.6 \mathrm{mM}$ potassium persulfate를 혼합하여 실온의 암소에 서 24시간 동안 방치하여 radical을 형성시킨 다음 실험 직 전에 $\mathrm{ABTS}$ 용액을 $732 \mathrm{~nm}$ 에서 흡광도가 $0.700 \pm 0.030$ 이 되도록 phosphate buffer saline(PBS, pH 7.4)로 희석하여 사용하였다. 희석된 용액 $950 \mu \mathrm{L}$ 에 추출물 $50 \mu \mathrm{L}$ 를 가하여 암소에서 10 분간 반응시킨 후 $732 \mathrm{~nm}$ 에서 흡광도를 측정하 였으며 계산식, ABTS radical scavenging ability(\%)= $100-[(\mathrm{OD}$ of sample/OD of control $) \times 100]$ 에 의하여 활성을
산출하였다.

Angiotensin l-converting enzyme(ACE) 저해활성 $\mathrm{ACE}$ 저해활성은 Cushman과 Chung의 방법(17)을 변형 하여 측정하였으며, 조효소액은 rabbit lung acetone powder (Sigma-Aldrich Co.)를 $0.2 \mathrm{~g} / 10 \mathrm{~mL}(\mathrm{w} / \mathrm{v})$ 의 농도로 $4^{\circ} \mathrm{C}$ 에서 24 시간 추출한 후, 원심분리 $\left(4^{\circ} \mathrm{C}, 4,000 \mathrm{rpm}, 40 \mathrm{~min}\right)$ 하여 상등액을 조효소액으로 사용하였다. 기질은 $0.3 \mathrm{M} \mathrm{NaCl}$ 이 함유된 $0.1 \mathrm{M}$ sodium borate buffer(pH 8.3)에 hippurylhistidyl-leucine(HLL, Sigma-Aldrich Co.)을 $5 \mathrm{mg} / \mathrm{mL}$ (w/v) 의 농도로 녹인 후 기질로 사용하였다. $\mathrm{ACE}$ 저해활성은 시료 $50 \mu \mathrm{L}$ 에 $\mathrm{ACE}$ 조효소액 $50 \mu \mathrm{L}$ 을 가한 다음 $37^{\circ} \mathrm{C}$ 에서 5 분간 예비 반응을 시킨 후, 기질 $50 \mu \mathrm{L}$ 을 가하고 다시 $37^{\circ} \mathrm{C}$ 에서 1 시간 반응시켰다. 다음 $1 \mathrm{~N} \mathrm{HCl} 150 \mu \mathrm{L}$ 을 가하여 반응을 정지시키고 $750 \mu \mathrm{L}$ 의 ethyl acetate를 가한 후, 1 분간 교반하고 원심분리 $\left(4^{\circ} \mathrm{C}, 5,000 \mathrm{mpm}, 10 \mathrm{~min}\right)$ 한 다음 $500 \mu \mathrm{L}$ 의 상등액을 얻었다. 이 상등액을 $120^{\circ} \mathrm{C}$ 에서 30 분간 완전히 건조시켜 $2 \mathrm{~mL}$ 의 methanol을 넣은 후 $228 \mathrm{~nm}$ 에서 흡광도를 측정하였다. 대조구로서는 추출물 대신 추출용매 $50 \mu \mathrm{L}$ 을 가하여 측정하였으며, 저해활성은 계산식, $\mathrm{ACE}$ inhibition $(\%)=\left[1-\left(\mathrm{C}_{\mathrm{Abs}}-\mathrm{S}_{\mathrm{Abs}}\right) /\left(\mathrm{C}_{\mathrm{Abs}}-\mathrm{B}_{\mathrm{Abs}}\right)\right] \times 100:$ " $\mathrm{C}_{\mathrm{Abs}}$; 대조구 흡광도, $\mathrm{S}_{\mathrm{Abs}}$; 시료 흡광도, $\mathrm{B}_{\mathrm{Abs}}$; 시료 무첨가구의 흡광도”에 의하여 산출하였다.

\section{통계처리}

모든 실험은 3 회 반복으로 행하여 평균치와 표준편차로 나타내었고, 유의성 검증은 version 12의 SPSS(Statistical Package for Social Sciences, SPSS Inc., Chicago, IL, USA) software package program을 이용하여 각 측정 평균값의 유의성 $(\mathrm{p}<0.05)$ 은 Duncan's multiple range test로 검정하 였다.

\section{결과 및 고찰}

\section{수율 및 색도}

건조방법에 따른 포도 송이가지 $70 \%$ 에탄올 추출 수율 및 색도는 Table 1과 같다. 수율은 ethanol extract of grape fruit stem with freeze drying(GFSF), ethanol extract of grape fruit stem with infrared drying(GFSI), ethanol extract of grape fruit stem with heat air drying(GFSH) 및 ethanol extract of grape fruit stem with sun drying(GFSS)가 각각 $59.17 \%$, $57.13 \%, 58.57 \%, 58.87 \%$ 로 높은 수율을 보였으나 건조방법 에 따른 유의적인 차이는 없었다. Jeong과 Youn(18)의 건조 방법에 따른 포도씨 연구에서는 적외선건조에 의한 수율이 가장 높게 측정되었으며, 그 다음으로 열풍건조, 천일건조 및 동결건조로 나타나 본 연구결과와 상이하였다. 이는 포 
도씨와 포도가지의 차이로 생각되며, 식용식물 중의 플라 보노이드와 같은 페놀성 화합물은 수용성 또는 지용성으로 구분되어 있어 추출되는 용매에 따라 그 성분들이 달라지기 때문에 추출 수율에 있어서 차이를 나타내는 것으로 판단된 다(19). 포도 송이가지의 경우 비극성 용매에서도 가용성 고형분이 잘 용출된 결과로 사료된다. 색도에서는 적외선 건조, 열풍건조 및 천일건조에서 밝기를 나타내는 $\mathrm{L}^{*}$ 값은 감소하고 적색도를 나타내는 $a^{*}$ 및 황색도를 나타내는 $b^{*}$ 값은 증가하는 경향을 보였는데 이는 건조하는 과정 중에 온도의 영향에 따른 갈변현상에 기인하는 것으로 판단된 다.

Table 1. Yields, moisture content, and Hunter's color value of $70 \%$ ethanol extracts of grape fruit stem with different drying methods

\begin{tabular}{|c|c|c|c|c|c|}
\hline \multirow[b]{2}{*}{ Samples ${ }^{1)}$} & \multirow[b]{2}{*}{$\begin{array}{c}\text { Yields } \\
\text { (\%, dry basis) }\end{array}$} & \multicolumn{4}{|c|}{ Hunter's color value } \\
\hline & & $\begin{array}{c}\mathrm{L}^{*} \\
\text { (lightness) }\end{array}$ & $\begin{array}{c}\mathrm{a}^{*} \\
\text { (redness) }\end{array}$ & $\begin{array}{c}\mathrm{b}^{\star} \\
\text { (yellowness) }\end{array}$ & $\begin{array}{c}\mathrm{H}^{0} \\
\text { (hue angle) }\end{array}$ \\
\hline GFSF & $59.17 \pm 1.25^{2) \mathrm{NS} 3)}$ & $53.37 \pm 0.98^{\mathrm{a} 4)}$ & $5.77 \pm 0.14^{\mathrm{c}}$ & $8.60 \pm 0.17^{\mathrm{c}}$ & $68.31 \pm 0.63^{\mathrm{a}}$ \\
\hline GFSI & 57.93 & $49.25 \pm 0.99^{c}$ & $7.02 \pm 0.22^{\mathrm{a}}$ & $10.61 \pm 0.33^{\mathrm{b}}$ & $62.77 \pm 0.25^{\mathrm{c}}$ \\
\hline GFSH & 58 & $51.00 \pm 0.94^{\mathrm{bc}}$ & $6.50 \pm 0.27^{b}$ & $11.42 \pm 0.19^{\mathrm{a}}$ & $66.37 \pm 0.76^{b}$ \\
\hline GFSS & $58.87 \pm 1.81$ & $50.70 \pm 0.44^{b}$ & $6.73 \pm 0.09^{\mathrm{ab}}$ & $11.55 \pm 0.11^{\mathrm{a}}$ & 63.37 \\
\hline \multicolumn{6}{|c|}{$\begin{array}{l}\text { 1) Abbreviations: GFSF, ethanol extract of grape fruit stem with freeze drying; GFSI, } \\
\text { ethanol extract of grape fruit stem with infrared drying; GFSH, ethanol extract of } \\
\text { grape fruit stem with heat air drying; GFSS, ethanol extract of grape fruit stem } \\
\text { with sun drying. } \\
\text { 2) Values are means } \pm \text { SD of triplicate determinations. } \\
\text { 3) NS, not significant. } \\
\text { (4) Different sunerscrints within a column (a-c) indicate significant differences }(\mathrm{p}<0.05)\end{array}$} \\
\hline
\end{tabular}

\section{폴리페놀, 플라보노이드 및 프로안토시아니딘 함량}

포도에는 polyhydroxyflavan-3-ol units의 oligomer과 polymer인 프로안토시아니딘으로 정의되는 폴리페놀 화합 물이 각종 기능성을 나타내는 유용물질로 보고되고 있다 (20). GFSF, GFSI, GFSH, 및 GFSS의 총 폴리페놀, 플라보노 이드 및 프로안토시아니딘의 함량을 측정한 결과는 Table 2와 같다. GFSF, GFSI, GFSH 및 GFSS의 폴리페놀 함량은 $\mathrm{g}$ 당 각각 $270.09 \mathrm{mg}, 268.44 \mathrm{mg}, 252.49 \mathrm{mg}$, 및 $253.03 \mathrm{mg}$ 이 검출되었으며 동결건조 및 적외선 건조의 경우 대등한 함량 을 나타내었으나 열풍 및 천일건조에서는 감소하는 결과를 나타내었다. Kim 등(21)의 건조 조건별에 따른 홍삼의 연구 결과에서도 동결건조 및 적외선 시료에서 총 페놀 함량이 타 건조방법에 비해 높게 측정되어 본 연구 결과와 일치하 였다. 반면 GFSF, GFSI, GFSH, 및 GFSS의 플라보노이드 함량은 각각 $58.35 \mathrm{mg}, 64.57 \mathrm{mg}, 61.65 \mathrm{mg}$, 및 $59.46 \mathrm{mg}$ 으로 적외선건조, 열풍건조, 천일건조 및 동결건조 순으로 증가 하였으며, 이는 Kim 등(21)의 건조 방법에 따른 홍삼의 연구 에서의 연구결과와 일치하였으나 건조에 따른 직접적인 영향은 받지 않는 것으로 나타났다. 또한 Kim 등(22)은 적정 열처리는 식품성분 내 환원당과 질소화합물의 갈색화 반응 을 일으키며, 생성된 산물은 항산화 효과를 가진다고 보고 하여 본 연구에서 적외선건조, 열풍건조, 천일건조에서 플 라보노이드 함량이 증가하는 현상과 관련이 있는 것으로 여겨진다. 프로안토시아니딘 함량에서는 GFSF, GFSI, $\mathrm{GFSH}$, 및 GFSS가 $\mathrm{g}$ 당 각각 $193.47 \mathrm{mg}, 181.30 \mathrm{mg}, 159.60$ $\mathrm{mg}$ 및 $157.13 \mathrm{mg}$ 이 검출되었으며, 적외선건조, 열풍건조 및 천일건조가 동결건조에 비하여 각각 $6.29 \%, 17.51 \%$ 및 $18.78 \%$ 가 감소하였는데 이는 열처리 시 페놀성 화합물이 변형되어 그 함량이 감소한 것으로 판단된다(23). 한편 $\mathrm{Xu}$ 등(24)의 보고에 따르면 포도씨와 과피의 프로안토시아니 딘 함량을 vanillin- $\mathrm{H}_{2} \mathrm{SO}_{4}$ 법으로 측정한 결과 $\mathrm{g}$ 당 각각 61.30 $\mathrm{mg}$ 및 $7.40 \mathrm{mg}$ 에 이르는 것으로 보고하였으며, 또 Cosme 등(25)은 포도씨는 $34.80-91.90 \mathrm{mg}$, 과피는 $1.10-5.90 \mathrm{mg}$ 의 함량으로 보고하여 포도 송이가지의 프로안토시아니딘의 함량이 포도씨, 과피 등의 함량보다 월등히 높은 것으로 나타났다.

\section{$\mathrm{TLC}$ 에 의한 카테킨 정성분석}

Vanillin- $\mathrm{H}_{2} \mathrm{SO}_{4}$ 법은 프로안토시아니딘을 빠르게 정량하 기 위하여 일반적으로 사용되는 방법(12)으로 catechin monomers 뿐만 아니라 그의 polymer인 여러 프로안토시아 니딘 성분들을 특이적으로 발색시키기 때문에 catechin류

Table 2. Total polyphenol, flavonoid, and proanthocyanidin contents of $70 \%$ ethanol extracts of grape fruit stem with different drying methods

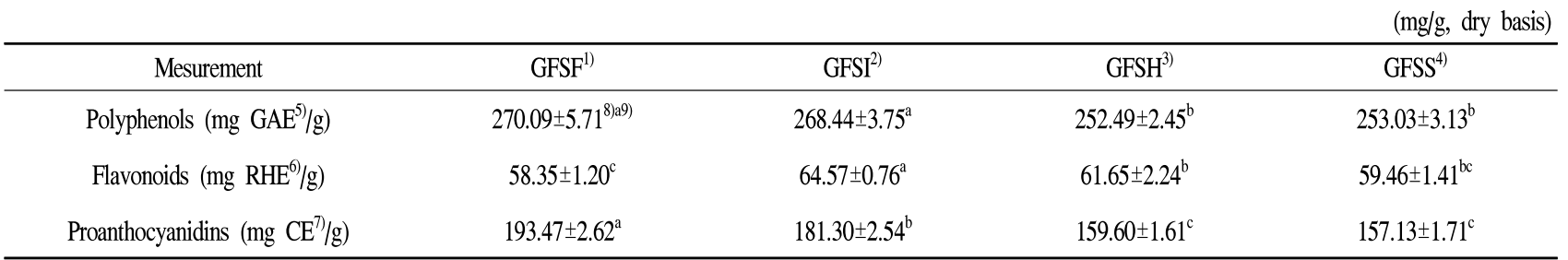

\footnotetext{
${ }^{1-4)}$ Abbreviations: GFSF, ethanol extract of grape fruit stem with freeze drying; GFSI, ethanol extract of grape fruit stem with infrared drying; GFSH, ethanol extract of grape fruit stem with heat air drying; GFSS, ethanol extract of grape fruit stem with sun drying.

${ }^{5-7)} \mathrm{GAE}$, gallic acid equivalents; RHE, rutin hydrate equivalents; CE, catechin hydrate equivalents.

${ }^{8)}$ Values are means \pm SD of triplicate determinations.

${ }^{9)}$ Different superscripts within a row $(a-d)$ indicate significant differences $(p<0.05)$.
} 


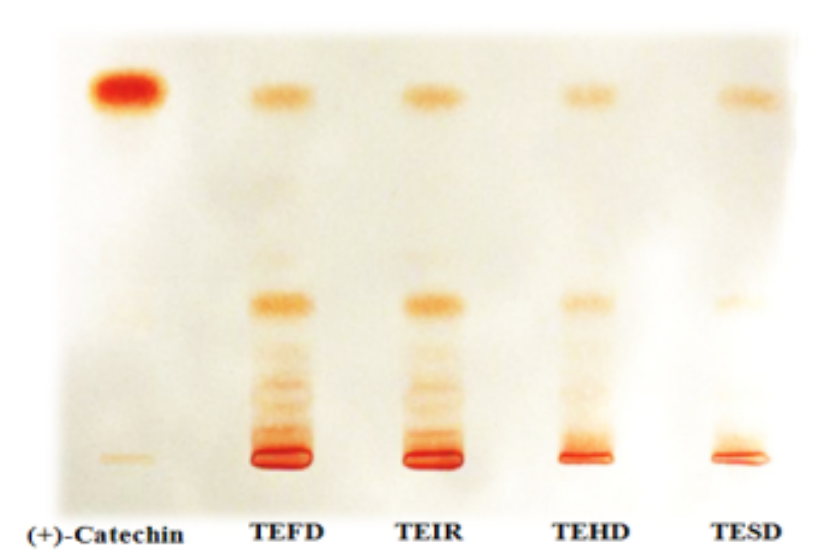

Fig. 1. TLC chromatogram of $70 \%$ ethanol extracts of grape fruit stem with different drying methods.

The spots were visualized by spraying with a $1 \%$ vanillin solution in $70 \%$ hydrochloric acid. The concentrations of test solutions were measured at 1,000 ppm.

의 정성 및 정량분석법으로 널리 사용되고 있다. GFSF, GFSI, GFSH, 및 GFSS 각각을 TLC에 $10 \mu \mathrm{L}$ 씩 spotting하여 catechin을 정성 분석한 결과는 Fig. 1과 같다. 모든 건조구 에서 catechin과 동일한 위치에서 band가 확인되었으며 동 결건조, 적외선건조, 열풍건조, 천일건조 순으로 선명한 적 색을 나타내어 프로안토시아니딘의 함량(Table 2)과 일치 함을 알 수 있었다. 한편 GFSF 및 GFSI에서 수종의 미세한 spot이 확인되었으나 GFSH 및 GFSS에서 발색정도가 감소 하는 것을 통해 열에 의한 성분의 손실이 있는 것으로 추정 되며, 적외선건조에서는 큰 영향을 미치지 않는 것으로 나 타났다.

\section{전자공여능}

GFSF, GFSI, GFSH, 및 GFSS의 전자공여활성을 천연 및 인공 항산화제로 알려진 L-ascorbic acid(AA), butylated hydroxyanisole(BHA), butylated hydroxytolune(BHT)와 비 교한 결과는 Table 3 과 같다. $50 \mathrm{\mu g} / \mathrm{mL}$ 의 낮은 농도에서는 건조 방법별 유의적인 차이는 없었으나 농도가 증가함에 따라 활성은 비례적으로 증가하였다. $500 \mu \mathrm{g} / \mathrm{mL}$ 의 농도에
서 $\mathrm{GFSF}, \mathrm{GFSI}, \mathrm{GFSH}$, 및 $\mathrm{GFSS}$ 의 전자공여 활성은 각각 $93.14 \%, 93.07 \%, 92.64 \%$ 및 $86.95 \%$ 로 동결건조, 적외선건 조 및 열풍건조가 천일건조에 비하여 유의적으로 높은 활성 을 나타내었다. Jeong 등(26)의 건조방법에 따른 가시오갈 피생약제의 연구에서는 열 풍건조보다는 동결건조에 따른 항산화 활성이 높아 본 연구와 일치하였으며, $\mathrm{Kim}$ 등(27)의 건조방법을 달리한 감말랭이의 연구에서는 감압건조, 적외 선건조, 냉풍건조, 열풍건조 순으로 $85.11-90.41 \%$ 의 범위의 활성으로 높게 측정되어 타 건조방법에 비해 적외선건조 제품에서 높은 항산화성을 나타내 본 연구 결과와 유사하였 다. $50 \mathrm{\mu g} / \mathrm{mL}$ 의 농도에서 대조군인 $\mathrm{AA}$ 및 $\mathrm{BHA}$ 는 각각 $97.82 \%$ 및 $82.61 \%$ 로 동일농도의 실험군에 비하여 높은 활 성을 나타내었지만 포도 송이가지 추출물의 농도가 증가함 에 따라 그 활성 역시 증가하기 때문에 기능성 소재로서의 활용도는 높을 것으로 사료된다.

\section{환원력}

$\mathrm{GFSF}, \mathrm{GFSI}, \mathrm{GFSH}$, 및 GFSS의 환원력을 측정한 결과는 Table 4 와 같다. 농도가 증가할수록 환원력도 유의적으로 증가하는 경향을 보였으며 동결건조, 적외선건조, 열풍건 조, 천일건조 순으로 나타나 Nam 등(28)의 건조방법에 따른 산사과 추출물 연구에서는 동결건조 시료에서 환원력이 높게 측정되어 본 연구 결과와 일치하였다. 반면 대조군 $\mathrm{AA}, \mathrm{BHA}$, 및 $\mathrm{BHT}$ 에 비해 낮은 흡광도를 나타내었다. Osawa(29)는 phenol성 물질은 항산화능을 포함한 다양한 생리적 효능을 나타내며 이는 주로 환원력에 의한 효과라고 보고한 바 있으며, 항산화 활성과 프로안토시아니딘 함량 사이에 상관성이 높다는 보고(30)로 비추어 볼 때 포도 송이 가지의 항산화 활성을 나타내는 주요 성분은 프로안토시아 니딘 성분일 것으로 추정되며 이들의 항산화력에 의한 결과 라 사료된다. 따라서 동결건조에서 환원력이 높은 현상은 이에 함유된 총 폴리페놀 및 프로안토시아니딘 함량에 기인 된 것으로 판단된다.

Table 3. Electron donating ability of $70 \%$ ethanol extracts of grape fruit stem with different drying methods

\begin{tabular}{|c|c|c|c|c|c|c|}
\hline \multirow{2}{*}{ Samples ${ }^{1)}$} & \multicolumn{3}{|c|}{ Concentration $(\mu \mathrm{g} / \mathrm{mL})$} & \multicolumn{3}{|c|}{ Positive control $\left.{ }^{2}\right)(50 \mu \mathrm{g} / \mathrm{mL})$} \\
\hline & 50 & 100 & 500 & $\mathrm{AA}$ & BHA & BHT \\
\hline GFSF & $24.37 \pm 0.85^{\left.3 \mathrm{a}_{4}\right)}$ & $46.83 \pm 1.53^{\mathrm{a}}$ & $94.14 \pm 0.64^{\mathrm{a}}$ & \multirow{4}{*}{$97.82 \pm 0.15^{\mathrm{A}}$} & \multirow{4}{*}{$82.61 \pm 1.05^{\mathrm{B}}$} & \multirow{4}{*}{$20.96 \pm 1.45^{\mathrm{C}}$} \\
\hline GFSI & $23.26 \pm 0.48^{a}$ & $46.44 \pm 1.20^{\mathrm{a}}$ & $93.07 \pm 0.57^{\mathrm{a}}$ & & & \\
\hline GFSH & $23.06 \pm 1.73^{\mathrm{a}}$ & $46.21 \pm 1.11^{\mathrm{a}}$ & $92.64 \pm 0.29^{\mathrm{a}}$ & & & \\
\hline GFSS & $23.09 \pm 0.72^{\mathrm{a}}$ & $39.21 \pm 0.74^{\mathrm{b}}$ & $86.95 \pm 0.32^{b}$ & & & \\
\hline
\end{tabular}

\footnotetext{
${ }^{1)}$ Abbreviations: GFSF, ethanol extract of grape fruit stem with freeze drying; GFSI, ethanol extract of grape fruit stem with infrared drying; GFSH, ethanol extract of grape fruit stem with heat air drying; GFSS, ethanol extract of grape fruit stem with sun drying.

${ }^{2)} \mathrm{AA}$, L-ascorbic acid; BHA, butylated hydroxyanisole; BHT, butylated hydroxytolune.

${ }^{3)}$ Values are means \pm SD of triplicate determinations.

${ }^{4)}$ Different superscripts within a column $(\mathrm{a}-\mathrm{c})$ and row $(\mathrm{A}-\mathrm{C})$ indicate significant differences $(\mathrm{p}<0.05)$.
} 
Table 4. Reducing power of $70 \%$ ethanol extracts of grape fruit stem with different drying methods

\begin{tabular}{|c|c|c|c|c|c|c|}
\hline \multirow{2}{*}{ Samples ${ }^{1)}$} & \multicolumn{3}{|c|}{ Concentration $(\mu \mathrm{g} / \mathrm{mL})$} & \multicolumn{3}{|c|}{ Positive control $^{2)}(50 \mu \mathrm{g} / \mathrm{mL})$} \\
\hline & 50 & 100 & 500 & $\mathrm{AA}$ & BHA & BHT \\
\hline GFSF & $0.316 \pm 0.008^{3) a 4)}$ & $0.636 \pm 0.008^{\mathrm{a}}$ & $1.933 \pm 0.023^{\mathrm{a}}$ & \multirow{4}{*}{$2.547 \pm 0.017^{\mathrm{A}}$} & \multirow{4}{*}{$2.578 \pm 0.019^{\mathrm{A}}$} & \multirow{4}{*}{$0.514 \pm 0.02^{\mathrm{B}}$} \\
\hline GFSI & $0.312 \pm 0.012^{\mathrm{a}}$ & $0.629 \pm 0.014^{\mathrm{a}}$ & $1.765 \pm 0.010^{\mathrm{b}}$ & & & \\
\hline GFSH & $0.248 \pm 0.005^{\mathrm{b}}$ & $0.621 \pm 0.008^{\mathrm{a}}$ & $1.455 \pm 0.026^{\mathrm{c}}$ & & & \\
\hline GFSS & $0.215 \pm 0.005^{\mathrm{c}}$ & $0.587 \pm 0.004^{b}$ & $1.200 \pm 0.016^{\mathrm{d}}$ & & & \\
\hline
\end{tabular}

${ }^{1)}$ Abbreviations: GFSF, ethanol extract of grape fruit stem with freeze drying; GFSI, ethanol extract of grape fruit stem with infrared drying; GFSH, ethanol extract of grape fruit stem with heat air drying; GFSS, ethanol extract of grape fruit stem with sun drying.

${ }^{2}$ AA, L-ascorbic acid; BHA, butylated hydroxyanisole; BHT, butylated hydroxytolune.

${ }^{3)}$ Values are means \pm SD of triplicate determinations.

${ }^{4}$ Different superscripts within a column $(\mathrm{a}-\mathrm{d})$ and row $(\mathrm{A}-\mathrm{B})$ indicate significant differences $(\mathrm{p}<0.05)$.

Table 5. ABTS radical scavenging ability of $70 \%$ ethanol extracts of grape fruit stem with different drying methods

\begin{tabular}{|c|c|c|c|c|c|c|}
\hline \multirow{2}{*}{ Samples ${ }^{1)}$} & \multicolumn{3}{|c|}{ Concentration $(\mu \mathrm{g} / \mathrm{mL})$} & \multicolumn{3}{|c|}{ Positive control $^{2)}(50 \mu \mathrm{g} / \mathrm{mL})$} \\
\hline & 50 & 100 & 500 & $\mathrm{AA}$ & BHA & BHT \\
\hline GFSF & $44.95 \pm 1.09^{3 / 24)}$ & $83.84 \pm 2.46^{\mathrm{a}}$ & $93.67 \pm 0.19^{\mathrm{a}}$ & \multirow{4}{*}{$98.61 \pm 0.13^{\mathrm{A}}$} & \multirow{4}{*}{$97.96 \pm 0.16^{\mathrm{B}}$} & \multirow{4}{*}{$90.96 \pm 0.61^{\mathrm{C}}$} \\
\hline GFSI & $42.41 \pm 2.63^{\mathrm{ab}}$ & $82.02 \pm 0.95^{\mathrm{ab}}$ & $93.20 \pm 0.12^{\mathrm{a}}$ & & & \\
\hline GFSH & $40.86 \pm 2.06^{b}$ & $80.07 \pm 2.12^{\mathrm{b}}$ & $91.60 \pm 0.81^{b}$ & & & \\
\hline GFSS & $29.68 \pm 1.04^{c}$ & $56.11 \pm 1.53^{\mathrm{c}}$ & $91.49 \pm 0.69^{b}$ & & & \\
\hline
\end{tabular}

${ }^{1)}$ Abbreviations: GFSF, ethanol extract of grape fruit stem with freeze drying; GFSI, ethanol extract of grape fruit stem with infrared drying, GFSH, ethanol extract of grape fruit stem with heat air drying; GFSS, ethanol extract of grape fruit stem with sun drying.

${ }^{2)}$ AA, L-ascorbic acid; BHA, butylated hydroxyanisole; BHT, butylated hydroxytolune.

${ }^{3)}$ Values are means \pm SD of triplicate determinations.

${ }^{4}$ Different superscripts within a column (a-c) and row (A-C) indicate significant differences $(\mathrm{p}<0.05)$.

\section{ABTS 라디칼 소거활성}

GFSF, GFSI, GFSH, 및 GFSS의 ABTS 라디칼 소거활성 을 비교한 결과는 Table 5와 같다. 농도가 증가함에 따라 그 활성도 비례적으로 증가하였으나 대조군 $\mathrm{AA}, \mathrm{BHA}$, 및 BHT보다는 낮은 활성을 나타내었다. 50-100 $\mathrm{\mu g} / \mathrm{mL}$ 의 농도 에서는 동결건조가 $44.95 \%$ 로 유의적으로 높게 측정되었으 며, 그 다음으로 적외선건조 및 열풍건조가 천일건조 순으 로 나타났다. 이는 Nam 등(28)의 건조방법에 따른 산사과 추출물 연구에서의 $\mathrm{ABTS}$ 라디칼 소거활성이 동결건조에 서 가장 높게 측정된 것과 일치하였다. $500 \mathrm{\mu g} / \mathrm{mL}$ 의 농도에 서는 다소 차이는 있으나 모든 건조구에서 비슷한 활성을
보였다. 한편 동일 농도 $(50-100 \mathrm{\mu g} / \mathrm{mL})$ 의 모든 처리구에서 $\mathrm{ABTS}$ 라디칼 소거능이 전자공여능에 비하여 월등히 높은 활성을 나타내는 것은 radical을 제거하는 기작이 다르고, 기질이 결합하는 정도가 다르다는 점에서 낮은 농도에서도 높은 활성을 나타내는 것으로 판단된다.

\section{$\mathrm{ACE}$ 저해활성 측정}

건조방법에 따른 포도 송이가지의 $\mathrm{ACE}$ 저해활성을 rutin 및 catechin과 비교한 결과는 Table 6과 같다. $500 \mu \mathrm{g} / \mathrm{mL}$ 농도에서의 $\mathrm{GFSF}, \mathrm{GFSI}, \mathrm{GFSH}$, 및 $\mathrm{GFSS}$ 의 $\mathrm{ACE}$ 저해활성 은 각각 $61.13 \%, 66.79 \%, 55.58 \%, 53.54 \%$ 로 적외선건조에

Table 6. Angiotensin converting enzyme(ACE) inhibitory activity of $70 \%$ ethanol extracts of grape fruit stem with different drying methods

\begin{tabular}{|c|c|c|c|c|c|c|}
\hline \multirow[t]{2}{*}{ Measurement } & \multirow[t]{2}{*}{ GFSF $^{1)}$} & \multirow[t]{2}{*}{$\mathrm{GFSI}^{2)}$} & \multirow[t]{2}{*}{$\mathrm{GFSH}^{3)}$} & \multirow[t]{2}{*}{$\mathrm{GFSS}^{4)}$} & \multicolumn{2}{|c|}{$\begin{array}{l}\text { Positive control } \\
(500 \mu \mathrm{g} / \mathrm{mL})\end{array}$} \\
\hline & & & & & Rutin & Cathechin \\
\hline $\begin{array}{l}\text { ACE inhibitory activity } \\
(\%, 500 \mu \mathrm{g} / \mathrm{mL})\end{array}$ & $61.13 \pm 2.10^{5 \mathrm{bb}}$ & $66.79 \pm 2.10^{\mathrm{a}}$ & $55.58 \pm 1.07^{\mathrm{c}}$ & $53.54 \pm 1.66^{\mathrm{c}}$ & $92.49 \pm 1.37^{\mathrm{A}}$ & $87.72 \pm 2.11^{\mathrm{B}}$ \\
\hline
\end{tabular}

\footnotetext{
${ }^{1-4)}$ Abbreviations: GFSF, ethanol extract of grape fruit stem with freeze drying; GFSI, ethanol extract of grape fruit stem with infrared drying; GFSH, ethanol extract of grape fruit stem with heat air drying; GFSS, ethanol extract of grape fruit stem with sun drying.

${ }^{5}$ Values are means \pm SD of triplicate determinations.

${ }^{6}$ Different superscripts within a row $(\mathrm{a}-\mathrm{c})$ and $(\mathrm{A}-\mathrm{B})$ indicate significant differences $(\mathrm{p}<0.05)$
} 
서 가장 높았고 다음으로 동결건조, 열풍건조, 천일건조 순의 활성을 나타내었다. 건조방법에 따른 항고혈압활성의 차이는 식물자원에 함유된 다양한 페놀화합물의 작용에 의한 가능성이 높다는 보고(31)와, 감나무 잎에서 분리한 페놀성 물질 중 플라보노이드성분이 $\mathrm{ACE}$ 저해활성을 높인 다는 보고(32)로 볼 때 포도 송이가지에 함유되어 있는 페놀 화합물에 기인한 것으로 추측된다. 한편 포도 송이가지 추 출물의 경우 대표 저해인자로 알려진 활성물질인 rutin (92.49\%)과 catechin(87.72\%)의 수준에는 미치지 못하나 높 은 활성을 나타내어 천연 항고혈압 소재로서의 이용가능성 을 예견케 하였으며 특히, 적외선건조 시 우수한 활성을 나타내어 산업적 활용에 기여할 수 있으리라 사료된다.

\section{요 약}

포도 부산물의 활용 및 생리활성 소재 개발 가능성을 알아보고자 건조 방법에 따른 포도 송이가지 $70 \%$ ethanol 추출물에 대한 생리활성을 측정하였다. 실험군은 포도 송 이가지 동결건조분말 $70 \%$ ethanol 추출물(GFSF), 적외선건 조분말 $70 \%$ ethanol 추출물(GFSI), 열풍건조분말 $70 \%$ ethanol 추출물(GFSH), 천일건조분말 $70 \%$ ethanol 추출물 (GFSS)을 각각 동결건조하여 실험에 사용하였다. 수율은 $\mathrm{GFSF}, \mathrm{GFSI}, \mathrm{GFSH}$, 및 GFSS가 각각 $59.17 \%, 57.13 \%$, $58.57 \%, 58.87 \%$ 로 높은 수율을 보였으나 건조방법에 따른 유의적인 차이는 없었다. 색도는 적외선건조, 열풍건조 및 천일건조에서 $\mathrm{L}^{*}$ 값은 감소하고 $\mathrm{a}^{*}$ 값 및 $\mathrm{b}^{*}$ 값은 증가하는 경향을 나타내었다. 폴리페놀 함량은 GFSF, GFSI, GFSH, 및 $\mathrm{GFSS}$ 가 $\mathrm{g}$ 당 각각 $270.09 \mathrm{mg}, 268.44 \mathrm{mg}, 252.49 \mathrm{mg}$ 및 $253.03 \mathrm{mg}$ 이였으며 플라보노이드 함량은 각각 58.35 $\mathrm{mg}, 64.57 \mathrm{mg}, 61.65 \mathrm{mg}$ 및 $59.46 \mathrm{mg}$ 이 검출되었다. 프로안 토시아니딘 함량에서는 $\mathrm{g}$ 당 각각 $193.47 \mathrm{mg}, 181.30 \mathrm{mg}$, $159.60 \mathrm{mg}$ 및 $157.13 \mathrm{mg}$ 이 검출되었다. TLC 분석 결과 모든 건조구에서 catechin과 동일한 위치에서 band가 확인 되었으며 동결건조, 적외선건조, 열풍건조, 천일건조 순으 로 선명한 적색을 나타내었다. $500 \mu \mathrm{g} / \mathrm{mL}$ 의 농도에서 $\mathrm{GFSF}, \mathrm{GFSI}, \mathrm{GFSH}$, 및 GFSS의 전자공여 활성은 각각 93.14\%, 93.07\%, 92.64\% 및 86.95\%로 동결건조, 적외선건 조 및 열풍건조가 천일건조에 비하여 유의적으로 높은 활성 을 나타내었고 환원력은 농도가 증가할수록 유의적으로 증가하는 경향을 보였다. $50-100 \mu \mathrm{gg} / \mathrm{mL}$ 의 농도에서의 $\mathrm{ABTS}$ 라디칼 소거활성에서는 동결건조, 적외선건조 및 열풍건조가 천일건조에 비하여 월등히 높은 활성을 나타내 었다. $500 \mathrm{\mu g} / \mathrm{mL}$ 농도에서의 $\mathrm{ACE}$ 저해활성은 $\mathrm{GFSF}, \mathrm{GFSI}$, $\mathrm{GFSH}$, 및 $\mathrm{GFSS}$ 가 각각 $61.13 \%, 66.79 \%, 55.58 \%, 53.54 \%$ 의 활성을 나타내었으며 적외선건조에서 가장 높은 저해활성 을 나타내었다. 이러한 결과를 종합해 볼 때 동결건조 및
적외선건조 포도 송이가지 추출물이 열풍건조 및 천일건조 에 비해 소재 활용가치가 높을 것으로 사료되며 천연항산화 제 및 기능성 증진을 위한 소재로 이용 가능할 것으로 판단 된다.

\section{감사의 글}

본 논문은 2017년도 대구가톨릭대학교 교내연구비 지원 에 의한 것으로 감사드립니다.

\section{References}

1. Halliwell B (2006) Reactive oxygen species and the central nervous system. J Neurochem, 59, 1609-1623

2. Hwang IT, Hwang JS, Lim HK, Park NJ (2010) Biorefinery based on weeds and agricultural residues. Korean J Weed Sci, 30, 340-360

3. Choi SW, Chung US, Lee KT (2005) Preparation of high quality grape seed oil by solvent extraction and chemical refining process. Korean J Food Preserv, 12, 600-607

4. Yoo MA, Chung HK, Kang MH (2004) Evaluation of physicochemical properties in different cultivar grape seed waste. Food Sci Biotechnol, 13, 26-29

5. Joe AK, Liu H, Suzui M, Vural ME, Xiao D, Weinstein IB (2002) Resveratrol induces growth inhibition. S-phase arrest, apophysis and changes in biomarker expression in several human cancer cell line. Clin Cancer Res, 8, 893-903

6. Gao X, Xu YX, Divine G, Janakiraman N, Chapman RA, Gautam SC (2002) Disparate in vitro and in vivo antileukemic effects of resveratrol, a natural polyphenolic compound found in grapes. J Nutr, 132, 2076-2081

7. Cho YJ, Kim JE, Chun HS, Kim CT, Kim SS, Kim CJ (2003) Contents of resveratrol in different parts of grapes. Korean J Food Sci Technol, 35, 306-308

8. Jo JE, Yook HS, Kim KH, Baek JY, Moon YJ, Park SJ, Jang SA (2010) Effect of drying methods and gamma irradiation on the color changes and antioxidant activity of grape by-products. J Korean Soc Food Sci Nutr, 39, 1826-1831

9. Yook HS, Kim KH, Jang SA (2010) Quality characteristics of grape pomace with different drying methods. J Korean Soc Food Sci Nutr, 39, 1353-1358

10. Dewanto V, Wu X, Adom KK, Liu RH (2002) Thermal processing enhances the nutritional value of tomatoes by 
increasing total antioxidant activity. J Agric Food Chem, 50, 3010-3014

11. Saleh ES, Hameed A (2008) Total phenolic contents and free radical scavenging activity of certain Egyptian Ficus species leaf samples. Food Chem, 114, 1271-1277

12. Sun B, Ricardo-da-silva JM, Sparangeer I (1998) Critical factors of vanillin assay for catechins and proanthocyanidins. J Agric Food Chem, 46, 4267-4274

13. Andriambeloson E, Magnier C, Haan-Archipoff G, Lobstein A, Anton R, Beretz A, Stoclet JC, Andriantsitohaina R (1998) Natural dietary polyphenolic compounds cause endothelium-dependent vasorelaxation in rat thoracic aorta. J Nutr, 128, 2324-2333

14. Blois MS (1958) Antioxidant determinations by the use of a stable free radical. Nature, 181, 1199-1200

15. Arabshahi-Delouee S, Urooj A (2007) Antioxidant properties of various solvent extracts of mulberry (Morus indica L.) leaves. Food Chem, 102, 1233-1240

16. Re R, Pellegrini N, Proteggente A, Pannala A, Yang M, Rice-Evans C (1999) Antioxidant activity applying an improved ABTS radial cation decolorization assay. Free Radical Biol Med, 26, 1231-1237

17. Cushman DW, Cheung HS (1971) Spectrophotometric assay and properties of the angiotensin-converting enzyme of rabbit lung. Biochem Pharmacol, 20, $1637-1648$

18. Jeong DS, Youn KS (2016) Comparison of the antioxidant and physiological activities of grape seed extracts prepared with different drying methods. Korean J Food Preserv, 23, 1-6

19. Cha JY, Jeong JJ, Kim YT, Seo WS, Yang HJ, Kim JS, Lee YS (2006) Detection of chemical characteristics in Hamcho (Salicornia herbacea) according to harvest periods. J Life Sci, 16, 683-690

20. da Silva JMR, Rigand J, Cheynier V, Cheminat A, Moutounet M (1991) Procyanidin dimers and trimers from grape seeds. Phytochemistry, 30, 1259-1264

21. Kim KY, Shin, JK, Lee SW, Yoon SR, Chung HS, Jeong, YJ, Choi MS, Lee CM Moon KD, Kwon JH (2007) Quality and functional properties of red ginseng prepared with different steaming time and drying methods. Korean J Food Sci Technol, 39, 494-499

22. Kim JH, Kwak DY, Choi MS, Moon KD (1999) Comparison of the chemial compositions of Korean and
Chinese safflower (Carthamus tinctororius L.) seed. Korean J Food Sci Technol, 31, 912-918

23. Kang HK, Yoo YK, Lee SK (2003) Effets of prestorage heat treatment on changes of phenolic compound contents and incidence of skin blackening in 'Niitaka' pear fruits during cold storage. J Korean Soc Hortic Sci, 44, 197-200

24. Xu C, Zhang Y, Cao L, Lu J (2010) Phenolic compounds and antioxidant properties of different grape cultivars grown in China. Food Chem, 119, 1557-1565

25. Cosme F, Ricardo-da-Silva JM, Laureano O (2009) Effect of various proteins on different molecular weight proanthocyanidin fractions of red wine during wine fining. Am J Enol Vitic, 60, 74-81

26. Jeong HN, Lim SH, Kim HY, Kim KD, Park YH, Ham HJ, Lee KJ, Kim KH, Ahn YS (2010) Quality changes in Eleutherococcus senticosus Cortex processed by different pretreatment and drying method. Korean J Med Crop Sci, 18, 98-104

27. Kim YS, Lee SJ, Kim MY, Kim GR, Chung HS, Paek HJ, Kim MO, Kwon JH. (2009) Physicochemical and organoleptic qualities of sliced-dried persimmons as affected by drying methods. Korean J Food Sci Technol, 41, 64-68

28. Nam S, Kwon YR, Chung HS, Youn KS (2016) Antioxidant abilities and physiological properties of dried Haw extracts prepared using different drying methods. Korean J Food Preserv, 23, 246-251

29. Osawa T (1994) Novel natural antioxidant for utilization in food and biological systems: In Postharvest Biochemistry of Plant Food Material in the Tropics. Japan Scientific Societies Press, Tokyo, Japan, p 241-251

30. Luximon-Ramma A, Bahorun T, Soobrattee MA, Aruoma OI (2002) Antioxidant activities of phenolic, proanthocyanidin, and flavonoid components in extracts of Cassia fistula. J Agric Food Chem, 50, 5042-5047

31. Kim KM, Suh HJ, hung SH, Cho WD, Ma SJ (1999) Chemical structure of angiotensin converting enzyme inhibitor isolated from onion flesh. Food Sci Biotechnol, $8,329-332$

32. Kameda K, Takaku T, Okuda H, Kimura H (1987) Inhibitory effects of various flavonoids isolated from leaves of persimmon on angiotensin-converting enzyme activity. J Nat Prod, 50, 680-683 